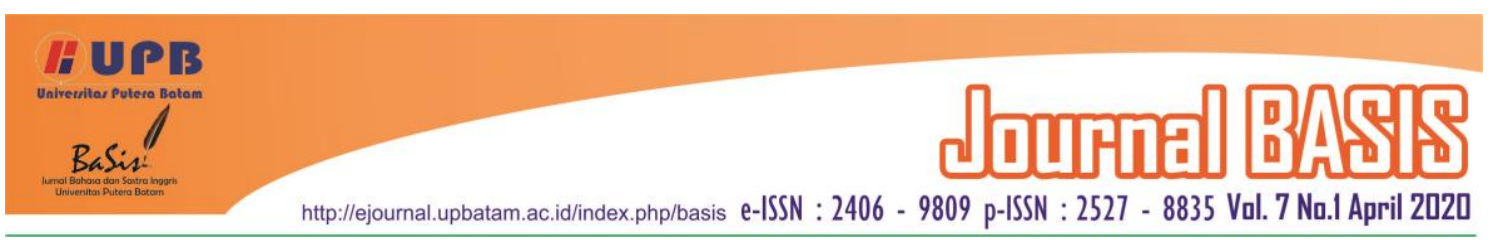

\title{
CODE SWITCHING ANALYSIS IN ENGLISH LITERATURE WHATSAPP GROUP
}

\author{
Thessa Cynthia Ameliza ${ }^{1}$ \\ Universitas Putera Batam (UPB), Batam, Indonesia \\ thessacynthia12@gmail.com ${ }^{1}$ \\ Ambalegin $^{2}$ \\ Universitas Putera Batam (UPB), Batam, Indonesia \\ ambalegin@upbatam.ac.id ${ }^{2}$
}

\begin{abstract}
The aim of this research was to find out the type and reason of code switching on WhatsApp group of Putera Batam University. In collecting the data, the research applied observational method nonparticipatory technique. The data was analyzed by using the theory of Poplack (1980). The researchers applied the text in WhatsApp as the data. It was found 15 texts contain code switching. The data ware classified into three: tag switching, inter-sentential switching and intra-sentential switching. From the 15 text, intra-sentential switching were the most frequent type of code switching because WhatsApp group members often change language from Indonesian to English in only a few sentences that appear at the beginning, in the middle, and at the end of sentence. Code switching have ten reason using theory of Grosjean (1981). First, to fill the linguistic needs for lexical items, specify phrases, discourse markers, or sentence fillers. Second, to continue the last language used (trigger). Third, quote someone. Fourth, to determine the recipient. Fifth, to qualify the message: strengthen or emphasize. Sixth, to determine the involvement of the speaker (personal message). Seventh, to mark and emphasize group identity. Eighth, conveys confidentiality, anger, and harassment. Ninth, to exclude someone from conversation. Tenth, change the role of the speaker: Increase status, add authority, and show expertise. For reasons in the WhatsApp group only 3 of 10 kinds of reasons were found: to fill the linguistic needs for lexical items, to continue the last language used (triggered) and to determine speaker involvement.
\end{abstract}

Keywords: Code Switching; Inter-sentence; Intra-Sentential; Tag.

\section{INTRODUCTION}

$$
\text { Bilingual or multilingual }
$$
communities switch to another language to signal group membership and share ethnicity with the recipient (Holmes, 2013). Indonesia is a bilingual country. Most people can speak two languages: first mother tongue, second national language. This happens because Indonesia is a multicultural country with a wide variety of cultures and languages. Someone said bilingual if he mastered two languages well. Indonesia can also be considered a multilingual country, especially in big cities that often intersect with foreign cultures. Most residents can not only speak their native language and national language, but can also speak a foreign language. Multilingual people say if he controls more than two languages well.

Research about code switching have been done before by some researchers. One of them is Supiastutik and Rudianto (2014). The research aimed to reveal it in detail and the data obtained will be analyzed using the Kruskal Wallis One Way Anova test by using the Chi-square value to determine 
its significance. A conclusion can be drawn that there is no positive relationship between the use of "code mixing" and "code switching" on the ability to master English subjects in SMK Widya 4 Batam Grade 11.

Second is from Kamariah and Ambalegin (2019). This research aims to describe the forms and the factors of using code switching that using in on Instagram. In this research found three kinds of code switching that using in instagram account they are: tagswitching, intersentential code switching, and intrasetential code switching. Based on of the types and analysis, researcher founds reasons of using code switching there are four points; Changing topic, Lack of vocabulary, Bilingual/multilingual, Prestige and trend.

Third is from Gross (2019). The current study examined processing of code-switching in Spanish-English bilingual children (ages 6;0-11;10) using an auditory moving window paradigm. Taken together, the findings provide limited support for a role of cognitive control in children's codeswitching processing and suggest that the processing costs incurred may be transitory.

Fourth is from Long (2014). In this paper, we focus on the acoustic data augmentation for the Mandarin-English CS speech recognition task. Effectiveness of conventional acoustic data augmentation approaches are examined. Finally, code-switching speech synthesis system is introduced to further enhance the acoustic modeling. Experimental results on the OC16CE80 data, a Mandarin-English mixlingual speech corpus, demonstrate the effectiveness of the proposed methods.
Code switching has become a general term for alternative uses of two or more languages, or types of language or even speech style. Those who speak several languages will often slip other languages into speaking activities. The reason research chose the analysis code switching because it is one of the eyes of the study that is easily understand. So, it was easier to see all the comments of the members of the WhatsApp group. In line with that explanation, students of the English Department can be considered bilingual because they have the ability to speak English since they enter the department. Therefore, English Department Students tend to use code switching in their communication with others. This research analyzed the type and reason of code switching in the English Literature Whatsgroup of Putera Batam Universisty.

\section{CODE SWITCHING}

Trousdale (2010) defines that code switching is a linguistic situation where the speaker will switch between two varieties (codes) in a conversation with another person who has the same linguistic repertoire. Hammer and blanc (as cited in Supiastutik \& Rudianto. 2014) code switching is a language contact communication strategy, speakers of language transfer elements or other language rules. However, various researchers have proposed that code switching is also commonly used by bilingual to achieve certain interaction goals in conversations with other speakers. Code switching can also be defined as alternating between two or more languages in the speaker's speech, occurs naturally in the quality scheme. Code switching unconsciously as the result of their capability of using more than one language, while another can appear code switching to repeat what 
was said before. Wardough (2006) indirectly, almost everyone masters more than one language. In switching codes, each language tends to support each function and each function according to the context. Switching in both cases has expressive functions and has meaning.

The most common description of code switching is that it involves the same use or during the same conversation. In the case of storytelling having two languages that are different from one another, it can accidentally change the language in one language, shift or style. Emphasizing the difference between mixing and displacement with reference to code switching when language changes occur across phrases or sentence boundaries, whereas code mixing occurs in sentences and usually involves one lexical item. It can be concluded that code switching is a symptom of shifting language use because of changes in roles and situations. Substitution code switching shows the interdependencies between contextual and situational functions that are relevant in the use of two or more languages.

Poplack (1980) categorized code switching into the following three types: Tag-switching, intrasentential and intersentential. Tag switching is sometimes called emblematic switching where a switch is just an interjection, a sentence filler in another language that serves as a marker of ethnic identity (Holmes, 2001). Such that consider Holmes in his agreement the tag is one that is not classified into interjection words. Some examples of interjections that go inside tag switching categories like Wow !, OY! Doh! Hello! Hi! Goodbye! Oh! Guys!. Intra-sentential switching can be considered to require greater fluency in both languages than tag switching because the main part of speech must be in accordance with the rules of both languages. With words otherwise, intra-sentential displacement can occur because of someone's fluency in master more than one language because its form is embedded in the sentence. Inter- sentential switching this is the most complicated type of code switching because the speaker must control two linguistic systems simultaneously (Poplack, 1980).

People might have different reasons why they use code switching in their conversations. Grosjean (1981) mentions ten reasons of switching. First, to fill the linguistic needs for lexical items, specify phrases, discourse markers, or sentence fillers. Second, to continue the last language used (trigger). Third, paraphrase someone. Fourth, determine the recipient. Fifth, To qualify the message: strengthen or emphasize. Sixth, Determine the involvement of the speaker (personal message). Seventh, Mark and emphasize group identity. Eighth, to convey confidentiality, anger, and harassment. Ninth,. To exclude someone from a conversation. Tenth, To change the role of the speaker: Increase status, add authority, and show expertise.

\section{RESEARCH METHOD}

There are two types of research designs; they are quantitative and qualitative research. Quantitative research is a method to find and collect data that can be measured with number and percentage. However, qualitative research has comprehension data and cannot be measured by numbers. Qualitative research has a descriptive base in order to understand a phenomenon more deeply. This research used descriptive qualitative 
method. Researchers used descriptive qualitative methods because the data in the form of words, phrases and sentences are not in the form of numbers. The descriptive qualitative method is applied.

The object of this is research is code switching. The theory of code switching is proposed by Poplack (1980). The code switching was analyzed in WhatsApp group comments. Researchers used a nonparticipatory observation method by Sudaryanto (2015) to collect data. Observation method is a method for collecting data by observing research objects in their context. Nonparticipatory techniques are type observation method to collect data without involving interaction with the speaker. The researcher uses this technique because the researcher does not engage in interaction with the speaker but only reads the comment.

The research used the categorization method to analyze the data. Categorization is an intuitive process that is systematic and reasoned based on the research goals, orientation and research's knowledge. The method for presenting research results is formal and informal (Sudaryanto, 2015). The formal method proposes the presentation of research results with formulations using numbers, signs and symbols. However, the informal method proposes ordinary words. This research uses informal methods in presenting the results of research. The informal method is used because the results of the analysis are in the form of sentences without numbers, signs and symbols.

\section{RESULT AND DISCUSSION}

\subsection{Result}

Based on the data were analysis, the researcher found the data which conducted as code switching. From this data, the researcher classifies based on the type of code switching and the reason for the use of code switching. The types of code switching are divided into three types, namely tag switching, intra sentential switching, and inter sentential switching. For reasons using code switching there are ten reasons such as, first, to fill linguistic requirements for lexical items, specifying phrases, discourse markers, or sentence fillers. Second, to continue the last language used (trigger). Third, paraphrase someone. Fourth, determine the recipient. Fifth, To qualify the message: strengthen or emphasize. Sixth, Determine the involvement of the speaker (personal message). Seventh, Mark and emphasize group identity. Eighth, to convey confidentiality, anger, and harassment. Ninth, to exclude someone from conversation. Tenth, To change the role of the speaker: Increase status, add authority, and show expertise. Those have been analyzed by theory Grosjean (1981).

Based on the analyzing above, the researcher found data which related with types of code switching. From the three types of code switching, the researcher found most of the data used intra sentential switching eight data. Then, from the several data the researcher also found tag switching one data and inter sentential switching five data. The second formulation is the reason for using code switching. There are ten reasons, but only three reasons were found in the data. The reasons used in the data are to fill the linguistic requirements for lexical items, to continue the last language used (triggered) and to determine speaker involvement. 
Vol. 7 No.l April 2020

e-ISSN : 2406 - 9809 p-ISSN : 2527 - 8835

httn://eiournal.upbatam.ac.id/index.pho/basis

+62 822-7659-5620

Guysss "ada gk yg pernah ngurus Ktm hilang???

\subsection{Discussion}

1. Types of Code Switching

1.1. Tag Switching

Tag switching occurs when tags from different languages are included in speech in other languages. Tag switching involves an exclamation tag, or parentheses in other languages. Tags are words or phrases added to sentences for emphasis. The example below meets the requirements as tag switching:

\section{+62 878-7455-7066 Andhika Saputra}

Teman2 tolong izinkan saya ya karena overtime.

\section{Terima kasih}

1. Aprisetiawaty's chat (14 August 2017)

One of the student in the group ask for someone who have done business with the student card. She asked how to make a new student card in the administration place in the campuss.

\subsection{Intra Sentential Switching}

A switch is called intra sentential switching when a switch occurs within sentence or clause boundaries. This type of code switching may appear at the beginning, in the middle, and at the end of a sentence. Examples of code switching can be seen as follows:

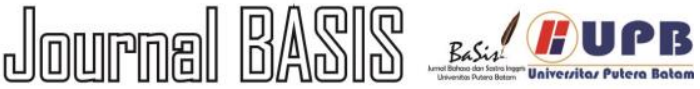

1. Meliana's chat (29 July 2018)

Meliana as the student in the group share information to the friends. She told about the paper as the assignement. Student who had not collected the paper was asked to collect it in the lecturer room. The paper must be submitted on top of the lecturer's table in the office.

+62 $8111-700-933$

Selamat pagi teman2, ada yg punya paspor.?

Saya ada promo tour ke malaysia 3 hari 2 malam , 1,6juta, berlaku khusus untuk besok, karna ada seat berlebih, 3 orang saja

2. Andhika's chat (9 April 2018)

Andika chat in the group about his presence. He could not attend the class because he worked overtime. He asked for help to our class to help him to tell the lecturer. It was the help to help him so he did not get the absent for zero score for the class.

3. Suliana's chat (25 Oktober 2018)

Suliana asked the group about the poetry subject. She asked about the book for the class subject poetry. She did not have any of the book. So she asked the group for anyone who owns a book. Shee would copy the book so she could own the book.

+62 853-5537-2699

Teman2 untuk yg submit paper klinik proposal nanti diletak aja diatas meja sir Tomi, hari ini last submit ya.

4. Gunawan's chat (20 February 2018) 
Gunawan chatted the group to his friends about vacation. He offered packet of vacation tour for someone who interested. There was a trip to Malaysia for 1.6 million rupiah. The offer for 3 people only. In order to take the offer, there must be passport for the student.

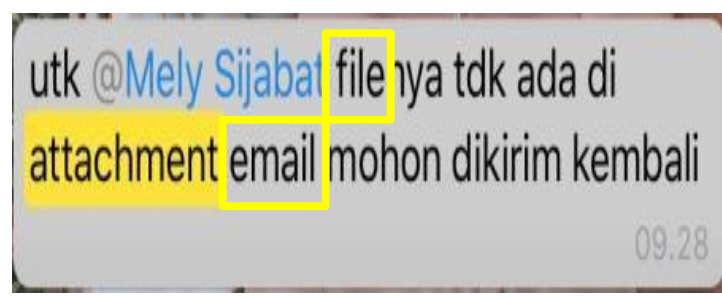

\section{Reika's chat (13 May 2018)}

Reika shared information to the group. She pointed Meliana that the file did not show at the attachment on the email. Reika asked her to send the file back to correct the failure. It was for the file for the assignemtn. It was a help so Meliana could get score.

\section{+62 857-6188-9697}

Tak ku sangka group ini saling berbagi nya luar biasa beda dengan yang lain

\section{Dina's chat (25 May 2018)}

Dina need for help for the group. She asked for the person who gave presentation about the semantic subject in meeting 5. She needed the presentation slide to study. The group responded by giving her the slide.
7. Gunawan's chat (9 September 2019)

Gunawan was chatting with Sunday about a key for motorcycle wheel. Sunday asked about the price for the key. Instead giving him the price, Gunawan answered by suggesting him about buying a new tire. Gunawan offered a better solution for Sunday.

\section{Andi's chat (20 November 2019)}

Andi surprised that the group was better than what he thought it was. The group cooperate better than before. Andi said that he was impressed by the team work in the class. He could see that from the conversation in the group.

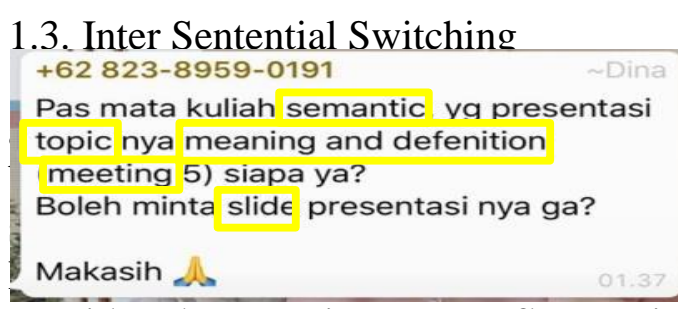
considered to require greater fluency in both languages than tag switching because the 4 main parts of speech must comply with the rules of both languages.

1. Nina's chat (19 Agust 2018)

Nina need for help in the group.

+62 811-700-933

@Sunday kamu beli kunci kunci itu mau 200ribu, bagus beli ban tubeless dengan harga yg sama 
class. It was for she did not get zero score in the class.

yg sesi malam tolong ijini dong ga masuk sesi 1 ... tu surat oti nya0

thanks before doing the theis. All the people also helped too.

+62 853-5537-2699

Konsul ke aku juqa boleh.. linguistic pragmatic approach

2. Ilham's chat (29 September 2018)

+62 821-7034-4310 ilham Rizki

gak usah di bahas

ayok keliling cari makanan gratis?

how about that?

+62 813-7820-9711

Terimakasih ya kepada tmn2 smw. Kalo aku ada salah kata slama proses pembelajaran, ataupun kurang bisa membantu saat kalian butuh aq, aq mohon maaf y smw. Smqa silaturahmi slalu terjalin. TQ ALL. LOVE U. .

passea tne Imal tnesis. Inere was tne lists who passed the final thesis from the group class. There were 12 people. All the friends said congratulations too. Elfi also hoped that all the knowledge will be useful for the future.

4. Meliana's chat (13 July 2019)

Meliana helped the fiend who needs some suggestion for the final thesis. She aldready passed the final thesis in the previous semester. She volunteer to help the firend who were
5. Depi's chat (19 November 2018)

Depi just graduated from the university. She said thanks for the class for all the journey together from the college. She also said sorry for the mistakes she made in the class. She said thankyou and lots of love.

2. The Reason in using code

+62 813-7203-8326
+62 813-6424-3335
congratu Photo
semoga ilmuny bermanfaat
that nas a Iong expranation, and the
speaker can decide to use both
languages in one conversation. When
two languages switch or combine two
languages, there may be motivation and
reasons for code switching and code
mixing. According to Grosjean (1981)
there are ten reasons for using code
switching. First, to fill the linguistic


needs for lexical items, specify phrases, discourse markers, or sentence fillers. Second, to continue the last language used (trigger). Third, quote someone. Fourth, determine the recipient. Fifth, to qualify the message: strengthen or emphasize. Sixth, to determine the involvement of the speaker (personal message). Seventh, to mark and emphasize group identity. Eighth, conveys confidentiality, anger, and harassment. Ninth, to exclude someone from conversation. Tenth, to change the role of the speaker: Raise status, add authority, and show expertise. Of all the reasons in using code switching explained by grosjen, In the WhatsApp group at Putera Batam University only found three out of ten reasons.

1. To fill a linguistic need for lexical item, set phrase, discourse marker, or a sentence filler.

For the first reason, group members prefer to replace words or phrases that are difficult to explain in Indonesian with the right sentences so that it is better to express them in English.

Sunday'-s Ghat2(25 Agust 2018)
Sore man teman
Sekedar info, bagi yang belum cek
turnitin jurnal atau pun jurnal yang masih
di atas 35\% bisa kirim file nya ke email
miss ana Afrianaupb@gmail.com
untuk segera di cek turnitinnya. Setelah
kirim, harap konfirmasi lg ke miss ana
lewat wa yaaa..
Tq

In the data, Sunday uses the English word "file", because she feels using the word will make the reader easier to understand than using the Indonesian language.

2. To continue the last language used (triggering).

\section{9)}

Sunday's Chat (28 November

\section{HELP}

ada yang punya sepatu safety dan kacamata bening (yg biasa di PT). Aku sewa lah untuk besok 1 hari.

\section{PLEASE}

kan yy

Ygdiserahin ke bak

It can be indicated that this data is

included in the transition trigger. Sunday uses the word "help" at the beginning of a sentence to indicate that he really needs rocks, at the end of the sentence he adds the trigger word "Please" so that one of the group members can help him.

3. To specify speaker involvement

Here, group members talk about who hasn't yet checked out Turnity in Indonesian. She gives information to someone who has not done a turnity check so that they immediately send their journal to Miss Ana at 
Afrianaupb@gmail.com email. To specify speaker involvement

\section{CONCLUSION}

From the analysis, code switching used by the member of WhatsApp group Putera Batam University was discussed. The types and Reason of code switching analyzed are based on theory Poplack (1980) and Grosjean (1981). The members of WhatsApp group of Putera Batam University, use all types of code switching classified by Poplack (1980). They are tag switching, inter-sentential switching, and also intra sentential switching.

Tag switching or a switch at a tag, parenthesis or exclamation which are included as part of tag switching, are entirely different languages. Intra sentential switching involved a switch of word or phrase. It occurs in the beginning, middle and the end of a sentence. Inter sentential switching or a switch at a clause or sentence boundary. The type of code switching that mostly occurs in the data is intra sentential switching, while the less occurrence is tag switching. From ten reasons of code switching stated by Grosjean, three of them are applicable here. Those are: To fill a linguistic need for lexical item, to continue the last language used (triggering) and to specify speaker involvement.

\section{REFERENCE}

Grosjean, F. (1981). Life with two languages: an introduction to bilingualism. Cambridge: Harvard University

Gross, M. C. . (2019). Processing of code-switched sentences by bilingual children: Cognitive and
Linguistic predictors. Cognitive Development, 52(3), 142-155. https://doi.org/10.1016/j.cogdev.20 19.100821

Holmes. (2001). An Introduction to Sociolinguistics. Edinburgh: Person Education Limited

Jendra, M. I. I. (2010). Sociolinguistics: The study of societies languages. Yogyakarta: Graha Ilmu.

Kamariah \& Ambalegin. (2019). Analysis of using code switching in Instagram. Jurnal Basis, 6(2), 259266.

https://doi.org/10.33884/basisupb.v $6 \mathrm{i} 2.1431$

Long, Y. (2014). Acoustic data augmentation for Mandarin-English code-switching speech recognition. Applied Acoustics, 161(3), 575580.

https://doi.org/10.4304/tpls.4.3.575 $-580$

Poplack. (1980). Sometimes I'll start a sentence in Spanish Termino En Espanol: toward a typology of code-switching. Linguistics, 18(8), 581-618.

Sudaryanto (2015). Metode dan aneka teknik analisis bahasa. Yogyakarta, Indonesia: Sanata Dharma University Press.

Supiastutik \& Rudianto. (2014). Pengaruh "Code Mixing" dan "Code Switching" terhadap kemampuan pemahaman Bahasa Inggris. Jurnal Basis, 1(2), 87-97. http://ejournal.upbatam.ac.id/index. php/basis/article/view/300 
Vol. 7 No.I April 2020

e-ISSN : $2406-9809$ p-ISSN : $2527-8835$

http://ejournal.upbatam.ac.id/index.php/basis

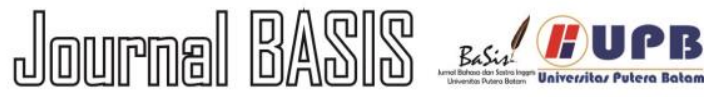

Trousdale, G. (2010). Introduction to

English Sociolinguistics.

Endingburgh: University press.

WhatsApp group of English

Department of Putera Batam

University. 